\title{
PHILOSOPHY
}

(THE JOURNAL OF THE BRITISH INSTITUTE OF PHILOSOPHY) 


\title{
PHILOSOPHY \\ (THE JOURNAL OF THE BRITISH INSTITUTE OF PHILOSOPHY)
}

\author{
EDITED BY \\ SYDNEY E. HOOPER
}

WITH THÉ ASSISTANCE OF

S. ALEXANDER WILLIAM BROWN

M. GINSBERG

G. DAWES HICKS

JULIAN S. HUXLEY
F. B. JEVONS HAROLD J. LASKI

A. D. LINDSAY JOHN S. MACKENZIE J. H. MUIRHEAD CLEMENT C. J. WEBB
BERTRAND RUSSELL

L. S. STEBBING

G. F. STOUT

A. E. TAYLOR

J. ARTHUR THOMSON

VOL. VII.-I932

LONDON :

MACMILLAN \& CO., LIMITED

ST. MARTIN'S STREET, W.C. 
PRINTED IN GREAT BRITAIN

BY UNWIN BROTHERS LIMITIT

LONDON AND WOKING 


\section{CONTENTS OF VOLUME VII}

\section{ARTICLES.}

ALExander S.-Poetry and Prose in the Arts (I) -

I" Poetry and Prose in the Arts (II) - - _ - _ -

BurReIL, P. S.-Man the Measure of All Things: Socrates versus Protagoras 153

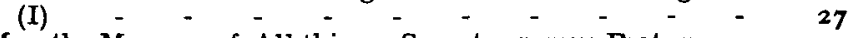

Man the Measure of All things: Socrates versus Protagoras

Clarke, Mary Evelyn.-A Phenomenological System of Ethics (I) - -

D'ARCY, THE Most REV. C. F. - Theism and Recent Philosophical Speculation

Drever, James. - The Present Position in Psychology

Evans, V. Burdwood. - The Aquinate Proofs of the Existence of God -

FAwCETt, Douglas.-On Fundamentals: An Adventure - - - -

ForsYrH, T. M.-The New Cosmology in its Historical Aspect: Plato,
Newton, Whitehead -

GAIIIE, IAN.—Oxford Moralists

GINSBERG, MORRIS.-History and Sociology - - - - - -

GuNN, J. A.-Renouvier: The Man and his Work (I) - - - - -

" Renouvier: The Man and his Work (II) - - - - - -

HOA F, $\mathbf{R}$-Indeterminacy and Indeterminism

JEAYs, SIR J - The Mathematical Aspect of the Universe - - - - -129

JoHNSTONE, JAMES.-Entropy and Evolution - - - - - - - -4283

KAYE, M-Tradition - - - - - - 68

Kelly, A. D., and Stebbing, L. S.-Discussion: Some Aspects of the

"New Logic"

LAIRD, JOHN.-The Obsequies of Realism

LWWIS, JoHn - How to Teach Philosophy

LODGE, SIR OLIVER. - The Physical Aspect of the Universe - $-z_{-}-\overline{-}^{-} 454$

PERrY, R. B.-Real and Apparent Value - - - - - - - 62

Rowell, E. M.-The Size-factor in Art - - - - - - - 320

TURNer, J. E.-Professor Stout's Realism: A Criticism - - - - $\quad 454$

TYRReLL, G. N. M.-Physics and the Ontological Problem - - - - 404

\section{PHILOSOPHICAL SURVEYS.}

Philosophy In France.-S. V. Keeling - - - - - - - $\quad-\quad-76,327$

Philosophy in Germany.-Helen Knight $\quad-\quad-\quad-\quad-\quad-\quad-80,331$

Phmosophy in Italy.-Guido de Ruggiero - - - - - - - $\quad 215,468$

PhILOSOPHY IN RussiA.-Natalie A. Duddington - - - - - 218, 471

\section{NEW BOOKS.}

ATYar, K. A. KIRshnaswamy.-Vedanta, or the Science of Reality (J. Woodroffe)

ARMITAGE D M-A Challenge to Neurasthenia (A. E Elder) - Ior

BAlliIE, J. B. (Translator).-Hegel's Phenomenology of Mind (J. S. Mackenzie) II7 


\section{CONTENTS}

Bennetr, C. A.-The Dilemma of Religious Knowledge (E. S. Waterhouse) Brinton, H. H.-The Mystic Will. Based on a Study of the Philosophy of Jacob Boehme (E. S. Waterhouse)

Burnham, J., and WheeIWright, P.-Philosophical Analysis (E. M. Whetnall)

Campbell, Chardes A.-Scepticism and Construction (B. M. Laing) - -

Candeloro, G.-Lo svolgimento del pensiero di Guiseppe de Maistre (T. E. Jessop)

Carbonara, C.-Léon Brunschvicg (T. E. Jessop)

Carriti, E. F.-Philosophies of Beauty (T. E. Jessop)
Conger, G. P.-A World of Epitomizations: a Study in the Philosophy of the Sciences (R. B. Braithwaite)

CRUTCHER, R.-Personality and Reason (H. D. Oakeley) - - - -

DAYal, H.-The Bodhisattva Doctrine in Buddhist Sanskrit Literature (C. A. F. Rhys Davids

Della VolPe, G.-La Teoria delle passioni di Davide $\bar{H}^{-} \overline{H u m e}^{-}$(T. E. Jessop)

Dickinson, G. Lowes.-J. McT. E. McTaggart (C. D. Broad) " Plato and His Dialogues (G. C. Field)

Dive" H 'Hence and Human Experience (G. B Brown) - - - 49

Eaton, Ralph M.-General Logic (G. Ryle) - - -

EмmeT, D. M.-Whitehead's Philosophy of Organism (A. D. Ritchie) - $\quad$ - 370

ENG, H.-The Psychology of Children's Draveings (V. Hazlitt) - - - 366

EvereTT, C. W.-The Education of Jeremy Bentham (A.Wolf) - - - $\quad 500$

Fawcett, Douglas.-The Zermatt Dialogues (J. E. Turner) - - - 228

Finer, H.-The Theory and Practice of Modern Government (A. K. White) - 495

Foster, G. B.-Friedrich Nietzsche (A. Wolf) - - - - - - $\quad 365$

Fox, C.-The Mind and its Body: The Foundations of Psychology (F. Aveling) $1 \mathrm{I} 2$

Garnetr, A. Campbell.-The Mind in Action. A Study of Motives and Values. (J. Drever)

Gibson, A. BoYce.- The Philosophy of Descartes (B. M. Iaing) - - -

Griffin, A. K. -Aristotle's Psychology of Conduct (G. C. Field) - - - 491

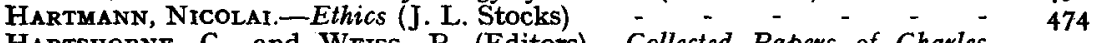

Hartshorne, C., and Weiss, P. (Editors).-Collected Papers of Charles Sanders Peirce. Vol. I, Principles of Philosophy (J. H. Muirhead) - - $\quad 245$

Harwood, J. (Translator).-The Platonic Epistles (G. C. Field) - - - $49 \mathrm{I}$

HEARD, G.-Social Substance of Religion (A. E. Garvie) - - - - $\quad$ log

HEATH, Sir T.-A Manual of Greek Mathematics (T. Greenwood) - - 361

HogBen, L.-Genetic Principles in Medicine and Social Science (J. $\mathrm{H}$. Woodger)

JoAD, C. E. M.-Philosophical Aspects of Modern Science (A. Boyce Gibson)

JoHnstone, JAmEs. -The Essentials of Biology (E. S. Russell) - - -

KIRKPATRICK, E. A.-The Sciences of Man in the Making (Jas. Johnstone) -

Kretschmer, E.-The Psychology of Men of Genius (C. P. Blacker) - -

LAIRD, J.-Hume's Philosophy of Human Nature (A. Boyce Gibson) - -

"Knowledge, Belief and Opinion (John W. Harvey)

LEvi, A.-La filosofia di Tommaso Hobbes (T. E. Jessop) - - - - III

LtvY-BruHL, L.-La Mentalité Primitive (S. V. Keeling) - - - - - 346

MCDowall, S. A.-Biology and Mankind (Jas. Johnstone) - - - - $\quad$ - 355

McTagGart, J. McT. E.-Some Dogmas of Religion (S. V. Keeling) - - 341

Moscarini, F.-Cicerone e l'etica stoica nel libro III del "De Finibus" (T. E.

Jessop)

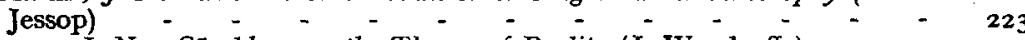

MUKERJI, J. N.-Sämkhya, or the Theory of Reality (J. Woodroffe) - - $\quad$ Io4

Nempham, J.-Chemical Embryology (Jas. Johnstone) - - - - - $\quad$ - 354

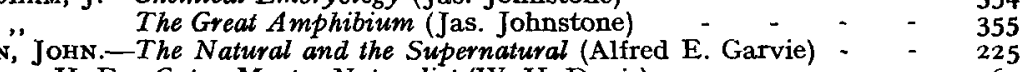

$\begin{array}{lll}\text { OMAN, JoHN.-The Natural and the Supernatural (Alfred E. Garvie) - } & - & 225 \\ \text { OsBorn, H. F.-Cope: Master Naturalist (W. H. Davis) - - - } & - & 363\end{array}$

Oтro, R.-Mysticism East and West: $A$ Comparative Analysis of the Nature of Mysticism (E. UnderhilI)

Parker, D. H.-Human Values (G. C Field)

Planck, M.-The Universe in the Light of Modern Physics (G. B. Brown) - $\quad 105$

Pollard, F. E.-Religion, Morals and the Intellect (E. S. Waterhouse) - 369

Porteus, S. D. -The Psychology of a Primitive People (R. R. Marrett) - 349

RaDhakrishnan, S.-An Idealist View of Life (W. R. Inge) - - - 477

Vi 


\section{CONTENTS}

RAMSEY, F. P. The Foundations of Mathematics and Other Logical Essays (B. Russell)

RAND, BENJAMiN (Editor).-An Essay Concerning the Understanding, Knowledge, Opinion, and Assent, by John Locke (H. H. Price) - - 247

RAYMONT, T.-Education (F. A. Cavenagh) - - - - - $\quad-364$

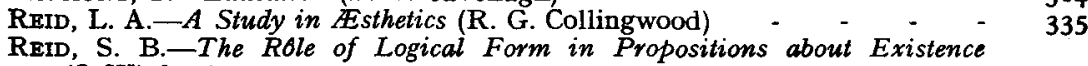
(J. Wisdom)

Russell., BerTRAND.-The Scientific Outlook (A. C. Ewing) - - - - - $\quad 345$

SAMUEL, SIR H.-Philosophy and the Ordinary Man (John Macmurray) - 334

SANDERS, C. F.-The Taproot of Religion and its Fruitage (E. S. Waterhouse) 360

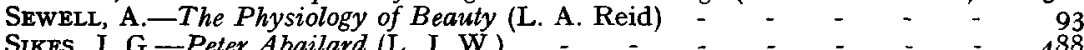

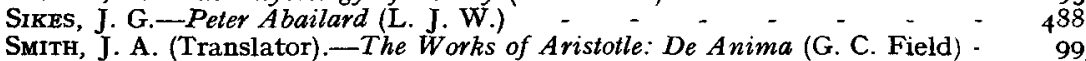

SMITH, N. KEMP. - Is Divine Existence Credible? (E. S. Waterhouse) - $\quad 349$

Stocks, J. L.-The Limits of Purpose and Other Essays (G. C. Field) - $\quad$ - 490

StouT, G. F.-Mind and Matter (B. M. Laing) - - - - - - 118

TSANOFF, R. A.-The Nature of Evil (W. O. Stapledon) - - - - 107

TURNER, J. E.-The Revelation of Deity (B. M. Laing) $-1-79$

URBAN, M. W.-Fundamentals of Ethics: An Introduction to Moral Philosophy
(G. C. Field)

VARIOUS AUTHORS.-Studies in the Nature of Facts (L. S. Stebbing) - - 486

$\begin{array}{rlll} & \\ & & 87\end{array}$

von HARTMaNn, E.-Philosophy of the Unconscious (B. M. Laing) - - 99

WEILEK, R. I Immanuel Kant in England (J. H. Muirhead) - - - 338

WEYL, H.-The Open World (L. S. Stebbing) - $\quad$ - $\quad$ - $\quad-\quad$ - 479

WHEELER, R. H.-The Laws of Human Nature (A. E. Elder) - - - - $\quad 353$

Whitraker, T.-Prolegomena to a New Metaphysic (A. C. Ewing) - - 360

WHYTE, L. L.-Critique of Physics (N. R. Campbell) - $-\quad-\quad-\quad-\quad 97$

WriLINK, M. D. R.-The Holy and Living God (E.S. Waterhouse) - - 117

WoLf, A.-Textbook of Logic (G. Ryle) - $-\begin{array}{lllll}- & - & - & - & 96\end{array}$

WoLFENDEN, J. F. The Approach to Philosophy (W. C. Kneale) - - 368

Y GASSET, J. O.-The Modern Theme (T. E. Jessop) - - - - - 352

ZmMern, H.-Schopenhauer: His Life and Philosophy - - - $\quad 4^{89}$

\section{CORRESPONDENCE.}

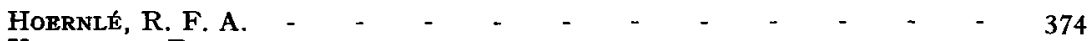

KeightLeY, B. - $\quad$ - $\quad-\quad-\quad-\quad-\quad-\quad-\quad-\quad-\quad-\quad-375$

KNIGHT, REX - $\quad-\quad-\quad-\quad-\quad-\quad-\quad-\quad-\quad-\quad-\quad-250$

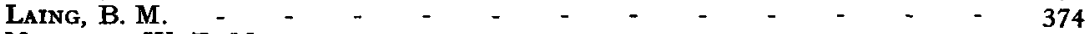

MITCHELI, W. E. M. - - - - - - - - - - - - $\quad$ - 502

RYLE, G. - - - - - - - - - - - - - - - 250

TURNER, J. E. - - - - - - - - - - -

INSTITUTE NOTES.

Annual Meeting -

I26

503

251

Letter to Press

Michaelmas Term

Manchester Centre

Summer Term -

Spinoza Tercentenary Meeting 